\title{
Diffusive gradients in thin films predicts crop response better than calcium-acetate-lactate extraction
}

\author{
Benjamin Hill · Jakob Santner · Heide Spiegel • Markus Puschenreiter • \\ Walter W. Wenzel(i)
}

Received: 22 February 2021 / Accepted: 15 September 2021 / Published online: 7 October 2021

(C) The Author(s) 2021

\begin{abstract}
Soil $\mathrm{P}$ testing has been widely used to predict crop yields, $\mathrm{P}$ uptake, and fertilizer demands in agriculture. Diffusive gradients in thin films (DGT) provides a zero-sink soil $\mathrm{P}$ test which mimics diffusion-controlled plant uptake and has previously been found to predict $\mathrm{P}$ availability to crops better than conventional quantity-based $\mathrm{P}$ tests in highly weathered Australian, though not in European soils. Here we tested the performance of DGT and the Austrian and German standard $\mathrm{P}$ quantity test calcium acetate lactate (CAL) to explain the variation of crop yield and $\mathrm{P}$ uptake response of winter wheat (Triticum aestivum L.) and spring barley (Hordeum vulgare L.) in long-term $\mathrm{P}$ fertilization experiments at four
\end{abstract}

B. Hill $\cdot$ J. Santner $\cdot$ M. Puschenreiter .

W. W. Wenzel $(\bowtie)$

Department of Forest and Soil Sciences, Institute of Soil

Research, University of Natural Resources and Life

Sciences Vienna, Konrad-Lorenz-Straße 24,

3430 Tulln an der Donau, Austria

e-mail: walter.wenzel@boku.ac.at

\section{J. Santner}

Department of Crop Sciences, Institute of Agronomy, University of Natural Resources and Life Sciences

Vienna, Konrad-Lorenz-Straße 24,

3430 Tulln an der Donau, Austria

\section{H. Spiegel}

Department for Soil Health and Plant Nutrition, Institute for Sustainable Plant Production, Austrian Agency for Health and Food Safety, Spargelfeldstraße 191, different sites in eastern Austria. Phosphorus extracted with DGT (P-DGT) and CAL (P-CAL) correlated well in similar soils but not across sites with large variation in soil and site properties such as carbonate equivalent and water availability. The predictive power of DGT for barley $\left(\mathrm{R}^{2}=0.42\right)$ and wheat grain yield $\left(\mathrm{R}^{2}=0.32\right)$, and $\mathrm{P}$ uptake in wheat grains $\left(\mathrm{R}^{2}=0.36\right)$ was clearly superior to that of the CAL, and less dependent on soil properties. The better performance of DGT compared to the quantity test is consistent with diffusion-limited $\mathrm{P}$ uptake in the water-limited cultivated soils of eastern Austria. The critical values of $\mathrm{P}$ deficiency derived from the Mitscherlich-type fits for barley and wheat at $80 \%$ relative yield are 64.9 and $26.2 \mu \mathrm{g} \mathrm{L}^{-1}$, respectively, consistent with differential P demands of the crops.

Keywords Diffusive gradients in thin films (DGT) . Phosphorus - Calcium acetate lactate extraction $(\mathrm{CAL}) \cdot$ Austria $\cdot$ Long-term field experiment

\section{Introduction}

Phosphorus $(\mathrm{P})$ is a critical component of cell membranes, nucleic acids, and the energy-rich molecule adenosine triphosphate (ATP), and is central in plant metabolism. Plant $\mathrm{P}$ status is therefore critical for maintaining agricultural productivity, which is 1220 Vienna, Austria 
reflected by the large $\mathrm{P}$ fertilizer inputs to managed soils worldwide. However, $\mathrm{P}$ is characterized by strong fixation and slow diffusion in soils, and therefore is often the limiting nutrient for plant growth. Furthermore, due to the unique chemistry of $\mathrm{P}$, the total amount measured in soils bears little relation to the fraction which may be available for plant uptake.

Plant nutrient demands can be expressed either by internal or external requirements. Internal requirements can be defined by the minimum nutrient uptake necessary to obtain a certain yield level or as nutrient concentration in plant tissue that is associated with near maximum yield. External requirements refer to the nutrient availability in the growth medium, i.e., typically soil. The concept of nutrient availability involves four aspects (Fox 1981; Peaslee and Phillips 1981), i.e. (1) capacity, (2) quantity, (3) intensity, and (4) (rate of) resupply and buffering. Capacity refers to the potential of a given soil to store a nutrient in plantavailable (labile) forms, whereas quantity is defined as the realization of this potential, often measured using an extraction method (e.g., Olsen, Mehlich, Bray or CAL) to target this nutrient pool. Intensity has been commonly defined as nutrient concentration in soil solution (Fox 1981). When plants take up nutrients from the soil solution, they deplete the available pool in the rhizosphere. Plant growth/productivity requirements can only be sustained if the rate of resupply, either through desorption from the solid phase and/or diffusion from the bulk soil towards the root surface equals or exceeds nutrient demand. The ability of the soil solid phase to replenish a nutrient has been described by buffer characteristics using the terms buffer power (BP) (Peaslee and Phillips 1981) or distribution coefficient $(\mathrm{Kd})$.

The relative performance of $\mathrm{P}$ quantity versus intensity tests has been a matter of debate for some time. Mechanistic modelling and related sensitivity analysis suggest that intensity generally determines uptake in plants more than quantity of $\mathrm{P}$ in soil (Barber 1995). However, intensive cropping of ryegrass in pot experiments has also shown that $\mathrm{P}$ quantity becomes increasingly important during extended cropping periods (Holford and Mattingly 1976).

According to Nawara et al. (2017), quantitycontrolled yield response occurs in sites that have low $K d$ (defined as the ratio between Olsen $\mathrm{P}$ and $0.01 \mathrm{M} \mathrm{CaCl}_{2}$-extractable), while intensity better explains yield response at large $K d$ values. However, this approach does not consider the extent of saturation of the sorption complex as suggested by Cole and Olsen (1959).

The kinetics of P release from the solid phase have been found to follow one fast and one subsequent slow reaction, assigned to two labile $\mathrm{P}$ pools with differential desorption kinetics (De Jager and Claassens 2005; Lookman et al. 1995; Maguire et al. 2001; MenezesBlackburn 2016; Smolders 2021; Taddesse et al. 2008). A recent experimental and modelling study demonstrates that $\mathrm{P}$ desorption rates control $\mathrm{P}$ availability to fast growing crops with small specific root area. This is even more relevant in soils with negative $\mathrm{P}$ balance as $\mathrm{P}$ desorption rates slow down, and may result in decreased $\mathrm{P}$ diffusion rates towards plant roots (Smolders et al. 2021).

Apart from differences in the concepts and methodologies to assess external $\mathrm{P}$ availability, crop response to soil $\mathrm{P}$ is further modified by climate and weather conditions, water availability and $\mathrm{P}$ mineralization from organic sources. Moreover, plant roots can actively change their soil environment through various root activities, including release of P-solubilizing compounds. Altogether, these factors and processes create additional variation in crop response that cannot be explained by any soil $\mathrm{P}$ test.

Most conventional tests use equilibrium-type extraction to target the quantity (e.g., Olsen or CAL) or intensity (e.g., water or $0.01 \mathrm{M} \mathrm{CaCl}_{2}$ extraction) of soil $\mathrm{P}$ for determining external $\mathrm{P}$ availability. Diffusive gradients in thin films (DGT) provide a more sophisticated sampling strategy that integrates quantity, intensity and the rate of resupply into one flux measurement in zero-sink conditions, where there is a continuous high concentration gradient between the solid phase and soil solution.

Similar to plant uptake under diffusion limitation, DGT deployment perturbs the solid-solution equilibrium, thus measuring the diffusive supply of an element as well as the resupply from the solid phase. Consequently, strong correlations have been observed between elemental concentrations in plants and those measured by DGT (Zhang et al. 2001, 2004; Song et al. 2004; Koster et al. 2005; Nolan et al. 2005). More recently, DGT has been applied as a tool to predict yield response and assess fertilizer requirements in agricultural systems. Experimental evidence suggests that DGT may be a useful tool to predict $\mathrm{P}$ deficiency 
and yield responses to $\mathrm{P}$ fertilization in strongly weathered soils of Australia, Africa and Vietnam (Menzies et al. 2005; McBeath et al. 2007; Mason et al. 2010a, b; Six et al. 2013). However, a recent study on temperate European soils indicates that DGT performs at best equal but not better in predicting yields and $\mathrm{P}$ uptake in various crops than some conventional soil $\mathrm{P}$ tests such as Olsen or ammonium lactate (AL) (Nawara et al. 2017). In field experiments in Denmark and Norway, Mundus et al. (2017) found stronger predictive power of DGT as compared to Olsen, AL and ammonium acetate for P concentration in the youngest fully emerged leaves of barley (Hordeum vulgare L.) sampled 30 days after sowing. However, none of the tests, including DGT, were able to predict $\mathrm{P}$ uptake and yield at the time of harvest. A pot experiment using soils from Denmark and Southern Sweden found that DGT performed better than Olsen in predicting $\mathrm{P}$ uptake in fully emerged young leaves of barley (Tandy et al. 2011).

Overall, there is still limited and confounding information on DGT as a tool for assessing $\mathrm{P}$ availability to crops and related critical values below which P deficiency occurs. Here, we follow up on the work discussed above by comparing the performance of DGT and CAL extraction for predicting crop yield and $\mathrm{P}$ uptake by addressing the following research questions:

(1) In view of its mechanistic advantages, does DGT predict $\mathrm{P}$ availability and related wheat and barley yield response better than the Austrian and German standard P test (CAL),

(2) does DGT provide an estimate of available P which is less influenced by soil and site conditions, and

(3) what are the critical values below which $\mathrm{P}$ deficiency occurs.

To answer these questions, we analyzed soil samples of $\mathrm{P}$ fertilizer response trials using DGT, located in the main arable farming areas in eastern Austria, and fitted the crop yields and plant $\mathrm{P}$ concentrations to the soil test results. We hypothesize that the performance of DGT in predicting grain yields is superior to CAL, and is less affected by soil properties.

\section{Materials and methods}

Site and soil characteristics

Soils were sampled from four different sites (Fig. 1), representing typical soil and climate conditions of the eastern Austrian lowlands. Site and soil description are compiled in Table 1 , the ranges of $\mathrm{P}$ concentrations extracted by calcium-acetate-lactate (P-CAL) and diffusive gradients in thin films (P-DGT) are shown in Table 2. The western sites in Rottenhaus and Grabenegg are characterized by lower mean annual temperature and higher precipitation as compared to those in Rutzendorf and Fuchsenbigl (eastern sites). This is reflected by the soils, with Chernozems in the latter, and Luvisols / Cambisols in the former sites (Table 1). Additionally, there is a clear differentiation regarding carbonate equivalent and soil $\mathrm{pH}$ between Rutzendorf/Fuchsenbigl (moderately to strongly calcareous, $\mathrm{pH}>7.5$ ) and the Rottenhaus/Grabenegg sites (slightly to non-calcareous, mean $\mathrm{pH}<6.5$ ).

Field trials

Experiment 1 is part of a long-term $\mathrm{P}$ fertilization study, initiated in 1956 by the Austrian Agency for Health and Food Safety (AGES). The experiment consists of two experimental sites, one in Fuchsenbigl (EXP 1 Fuchsenbigl) and the other in Rottenhaus (EXP 1 Rottenhaus). Utilizing randomized block design, both sites included five replicates of five different $\mathrm{P}$ fertilization treatments: no $\mathrm{P}$ addition, single superphosphate (SSP) and 'basic slag' (Thomas slag) at $\mathrm{P}$ application rates of $44 \mathrm{~kg} \mathrm{ha}^{-1} \mathrm{a}^{-1}$ and $175 \mathrm{~kg} \mathrm{ha}^{-1} \mathrm{a}^{-1}$. A detailed description is included in Spiegel et al. (2018). The plots were fertilized continuously from 1956 to 2004, and again in 2012. Both surface soil samples (0-25 cm depth) and winter wheat (Triticum aestivum L.) data (i.e., P concentrations in grain and grain dry matter yield) were obtained for the year 2013 .

Experiment 2 is a long-term $\mathrm{P}$ fertilization study, which investigates different crop residue management strategies. Commenced in 1982, the study is comprised of one experimental site in each of the Rutzendorf (EXP 2 Rutzendorf) and Grabenegg (EXP 2 Grabenegg) locations. Plots were fertilized with SSP at rates of $0,33,67,133 \mathrm{~kg} \mathrm{P} \mathrm{ha}^{-1} \mathrm{a}^{-1}$. The fertilization rates were duplicated for both residue 
Table 1 Site, soil and yield characteristics of the experimental sites (mean values and standard deviations)

\begin{tabular}{|c|c|c|c|c|c|c|}
\hline \multirow[t]{2}{*}{ Site } & & \multicolumn{2}{|l|}{ Experiment 1} & \multicolumn{2}{|l|}{ Experiment 2} & \multirow[t]{2}{*}{ All data } \\
\hline & & $\begin{array}{l}\text { Fuchsenbigl } \\
\text { (Eastern) }\end{array}$ & $\begin{array}{l}\text { Rottenhaus } \\
\text { (Western) }\end{array}$ & $\begin{array}{l}\text { Rutzendorf } \\
\text { (Eastern) }\end{array}$ & $\begin{array}{l}\text { Grabenegg } \\
\text { (Western) }\end{array}$ & \\
\hline Mean annual temperature ${ }^{\mathrm{a}}$ & ${ }^{\circ} \mathrm{C}$ & 10.3 & 9.5 & 10.3 & 9.5 & \\
\hline $\begin{array}{l}\text { Mean annual } \\
\text { precipitation }^{\mathrm{a}}\end{array}$ & $\mathrm{L} \mathrm{m}^{-2}$ & 516 & 696 & 516 & 696 & \\
\hline Soil group (WRB) & & $\begin{array}{l}\text { Calcic } \\
\text { Chernozem }\end{array}$ & $\begin{array}{l}\text { Stagnic } \\
\text { Luvisol }\end{array}$ & $\begin{array}{l}\text { Calcic } \\
\text { Chernozem }\end{array}$ & $\begin{array}{l}\text { Dystric } \\
\text { Cambisol }\end{array}$ & \\
\hline Textural class (FAO) & & Loam & Silt clay loam & Loam & Silt loam & \\
\hline Sand & $\mathrm{g} \mathrm{kg}^{-1}$ & 400 & 30 & 260 & 70 & \\
\hline Silt & & 420 & 670 & 510 & 770 & \\
\hline Clay & & 180 & 300 & 230 & 160 & \\
\hline $\mathrm{CaCO}_{3}$ equivalent & & $133 \pm 13$ & $0.36 \pm 1.4$ & $172 \pm 2.85$ & 0 & \\
\hline $\mathrm{SOC}$ & & $16.7 \pm 0.10$ & $19.3 \pm 1.37$ & $20.7 \pm 1.10$ & $8.53 \pm 0.45$ & $16.3 \pm 4.90$ \\
\hline $\mathrm{pH}\left(\mathrm{CaCl}_{2}\right)$ & & $7.53 \pm 0.03$ & $6.48 \pm 0.30$ & $7.63 \pm 0.05$ & $5.45 \pm 015$ & $6.74 \pm 094$ \\
\hline $\mathrm{K}-\mathrm{CAL}$ & $\mathrm{mg} \mathrm{kg}^{-1}$ & $16.7 \pm 0.10$ & $132 \pm 13$ & $213 \pm 45$ & $216 \pm 26$ & $158 \pm 52$ \\
\hline P-CAL & & $145 \pm 91$ & $52.8 \pm 47.9$ & $155 \pm 91$ & $85.3 \pm 52.0$ & $110 \pm 85$ \\
\hline P-CAL:P-DGT & $\mathrm{L} \mathrm{kg}^{-1}$ & $1091 \pm 248$ & $431 \pm 191$ & $1160 \pm 946$ & $462 \pm 228$ & $782 \pm 620$ \\
\hline Wheat yield & $\mathrm{kg} \mathrm{ha}^{-1}$ & $5720 \pm 488$ & $6660 \pm 672$ & & & $6210 \pm 753$ \\
\hline Barley yield & & & & $4390 \pm 642$ & $6160 \pm 671$ & $5270 \pm 1100$ \\
\hline
\end{tabular}

${ }^{\mathrm{a}}$ Mean 1981-2010 for the nearest station

Table 2 Critical values above which P deficiency occurs for P-DGT and P-CAL. Data in parenthesis represent the upper and lower limits of the $95 \%$ confidence interval

n.d determination not possible

\begin{tabular}{llllll}
\hline Experimental unit & \multicolumn{2}{l}{ Range of extracted P } & & \multicolumn{2}{l}{ Critial limits of P deficiency } \\
\cline { 2 - 3 } & $\begin{array}{l}\text { P-CAL } \\
\mathrm{mg} \mathrm{kg}^{-1}\end{array}$ & $\begin{array}{l}\text { P-DGT } \\
\mu \mathrm{g} \mathrm{L}^{-1}\end{array}$ & & $\begin{array}{l}\text { P-CAL } \\
\mathrm{mg} \mathrm{kg}^{-1}\end{array}$ & $\begin{array}{l}\text { P-DGT } \\
\mu \mathrm{g} \mathrm{L}^{-1}\end{array}$ \\
\hline All crops and sites & $9.0-351$ & $10.8-788$ & & $24.6(8.6-42.9)$ & $44.0(27.7-64.3)$ \\
Wheat (all sites) & $9.0-347$ & $23.0-443$ & & n.d & \\
Barley (all sites) & $19.0-351$ & $10.7-788$ & & $44.9(48.4-52.1)$ & $64.9(44.4-89.8)$ \\
Eastern sites (all crops) & $9.0-168$ & $21.5-788$ & & $59.2(29.4-97.2)$ & $46.6(25.7-75.1)$ \\
Western sites (all crops) & $30.0-351$ & $10.7-651$ & & $11.8(0-28.1)$ & $37.7(26.6-50.4)$ \\
\hline
\end{tabular}

incorporation and residue removal treatments. A detailed description is given in Spiegel et al. (2018). A total of four replicates were produced for each treatment. Yield data for barley (Hordeum vulgare L.), and the corresponding surface soil samples $(0-25 \mathrm{~cm})$ were collected in 2014.

\section{Determination of soil properties}

The soil characteristics presented in Tables 1 and 2 were analyzed according to Austrian standard procedures for soil testing. Soils were classified according to
IUSS Working Group WRB (2014). Soil texture was determined using a combined sieve and pipette method (ÖNORM L1061-2 2019), the data were used to assess the textural class according to FAO (2006). The $\mathrm{pH}$ was determined in $0.01 \mathrm{M} \mathrm{CaCl}_{2}$ solution with soil to solution ratio of $1: 2.5(\mathrm{v} / \mathrm{v})$ (ÖNORM EN 15933 2012). Soil organic carbon (SOC) was determined through combustion at $650{ }^{\circ} \mathrm{C}$ (ÖNORM L 1080, 1999), and the $\mathrm{CaCO}_{3}$ equivalent was determined according to the Scheibler method (ÖNORM L 1084 2006). 
Calcium acetate lactate extractable P (P-CAL)

P-CAL extraction, representing an equilibrium-type quantity $\mathrm{P}$ test, was performed according to the Austrian standard procedure (ÖNORM L 1087 2006). Briefly, $2.5 \mathrm{~g}$ of air-dried and sieved $(<2 \mathrm{~mm})$ soil was mixed with $50 \mathrm{~mL}$ extracting solution, consisting of $0.05 \mathrm{~mol} \mathrm{~L}^{-1}$ calcium lactate, $0.05 \mathrm{~mol} \mathrm{~L}^{-1}$ calcium acetate, $0.3 \mathrm{~mol} \mathrm{~L} \mathrm{~L}^{-1}$ acetic acid, pH 4, according to Schüller (1969). Samples were shaken end-over-end for $2 \mathrm{~h}$, after which they were filtered and measured photometrically using the molybdate blue procedure, as described in Zhang (1998).

\section{Plant digestion}

To determine $\mathrm{P}$ concentrations, wheat grains (Experiment 1) were dried overnight at $105{ }^{\circ} \mathrm{C}$ and digested in concentrated $\mathrm{HNO}_{3}$ and $\mathrm{H}_{2} \mathrm{O}_{2}(5: 1 \mathrm{v} / \mathrm{v})$. Phosphorus was measured using ICP-OES.

$\mathrm{P}$ sampled using diffusive gradients in thin films (P-DGT)

DGT samplers consist of a stacked assembly of a diffusive gel and a binding gel layers, both created with the same hydrogel formula, containing $15 \%$ by volume polyacrylamide and $0.3 \%$ by volume agarose derived cross-linker (Quernmore, Lancaster, U.K., www.dgtresearch.com). Diffusive and binding gels were prepared according to Zhang and Davison (1995), and Santner et al. (2010). Diffusive gels were cast by mixing the gel solution with ammonium persulfate $(10 \%)$ and TEMED catalyst in proportions according to Zhang and Davison (1995), and further processed as described by Santner et al. (2010). The finished ferrihydrite gels were washed in $1 \mathrm{~L}$ type 1 laboratory water $\left(0.055 \mu \mathrm{S} \mathrm{cm}{ }^{-1}\right.$ produced by a TKAGenPure purification system, Thermo Electron LED GmbH, Niederelbert, Germany) 2-3 times, and stored refrigerated in $30 \mathrm{mmol} \mathrm{L}{ }^{-1} \mathrm{NaNO}_{3}$.

The DGT samplers were assembled using plastic housing materials (Quernmore, Lancaster, U.K., www.dgtresearch.com) consisting of a backing cylinder and a cap with a $1.7 \mathrm{~cm}$ diameter exposure window. The samplers consisted of a $0.4 \mathrm{~mm}$ ferrihydrite gel, polycarbonate membrane (pore size $0.2 \mu \mathrm{m}$, thickness $10 \mu \mathrm{m}$; Nuclepore, GE Healthcare,
Freiburg, GER), $0.8 \mathrm{~mm}$ diffusive gel disc, and a 0.13 cellulose nitrate filter disc (pore size $0.45 \mu \mathrm{m}$, thickness $130 \mu \mathrm{m}$; Supor, Pall GmbH, Dreieich, GER). The polycarbonate membrane negligibly affects the diffusion process and prevents the ferrihydrite gel from sticking to the diffusive gel.

For each experimental soil, a pooled subsample was taken, and maximum water holding capacity (WHC) was determined by visual inspection by wetting soil until a paste formed and the surface was glistening. For DGT sampling, a soil paste was created by adjusting samples to $90 \%$ of the WHC, and allowing to equilibrate for $24 \mathrm{~h}$ at $20{ }^{\circ} \mathrm{C}$. Approximately $3 \mathrm{~g}$ of soil paste was then applied on top of the DGT samplers and incubated at $20{ }^{\circ} \mathrm{C}$ for an additional $24 \mathrm{~h}$. After exposure, samplers were carefully disassembled and gels rinsed with HQ water to remove any remaining soil particles. Ferrihydrite gels were then eluted in $5 \mathrm{~mL}$ of $250 \mathrm{mM} \mathrm{H}_{2} \mathrm{SO}_{4}$. Samples were shaken on a horizontal shaker overnight to elute.

Phosphorus analysis

Phosphorus concentrations in the eluates were determined using the molybdate blue procedure (Murphy and Riley 1962) on a Hitachi U-2000 UV/VIS spectrophotometer (Hitachi High-Technologies Corporation, Tokyo, Japan). The staining reagent was prepared by mixing $10 \mathrm{~mL} \mathrm{HQ}$ water, $3 \mathrm{~mL}$ of $9 \mathrm{mM}$ ammonium heptamolybdate and $1 \mathrm{~mL}$ of $4 \mathrm{mM}$ potassium antimony (III) tartrate hydrate. To produce the color reaction, $1 \mathrm{~mL}$ of sample, $0.14 \mathrm{~mL}$ of the staining reagent, and $0.06 \mathrm{~mL} 100 \mathrm{mM}$ ascorbic acid were mixed. After 15 to $20 \mathrm{~min}$, the color reaction had finished and the samples were immediately measured at $881 \mathrm{~nm}$ using a spectrophotometer.

Curve fitting and relative yield (RY) calculation

To compare grain yield across sites, we determined the maximum yield for each experimental block separately, by fitting a Mitscherlich-type curve between absolute grain yield and the rate of $\mathrm{P}$ applied, using the equation:

$y=y_{0}+a\left(1-e^{-b x}\right)$

where $y_{0}=$ yield of control plots ( $\left.0 \mathrm{P}\right), y_{0}+a=$ the maximum yield attainable, and $x=$ the $\mathrm{P}$ rate applied. 
Using this equation, we determined the maximum yield for each of the experimental blocks $(n=36)$ at each site, and calculated the relative yields for all treatments according to:

$$
R Y(\%)=\frac{y}{y_{0}+a} \times 100
$$

where RY refers to the relative yield.

For further analysis we only included P-responsive plots approaching a yield plateau in the highest $\mathrm{P}$ treatment, with goodness of Mitcherlich-type fits of $\mathrm{R}^{2} \geq 0.80$. Plots were considered as non-responsive if the relation between $\mathrm{P}$ application rate and yield was weak $\left(\mathrm{R}^{2}<0.80\right)$, or close to linear within the range of $\mathrm{P}$ applied. This is justified as the lack of a strong relation between $\mathrm{P}$ fertilizer input and yield response indicates that $\mathrm{P}$ was not the most limiting factor of yield, e.g., because of infection with pathogens, and because RY cannot be calculated using the Mitcherlich equation if the response is regular but linear. The approach follows established procedures of previous work (Burkitt et al., 2016; Mason et al. 2010a, b; Speirs et al., 2013). We then evaluated the relationships between soil test P (P-CAL or P-DGT) and yield by fitting a curve to the data from the remaining 16 experimental blocks, corresponding to 58 soil-RY pairs. To investigate differences in this relationship between crops, we also fitted curves for DGT and CAL separately for wheat and barley. Curve fitting was performed using Solver in Microsoft Excel (Version 15.33). Using inverse calculation from the Mitscherlich-type fits, critical values above which P deficiency occurs were obtained for P-CAL and P-DGT from the intercept of the fitted curve at $80 \% \mathrm{RY}$, along with the $95 \%$ confidence interval. To this end, we first calculated the confidence intervals for the $80 \% \mathrm{RY}$, and again applied inverse calculation to obtain the corresponding lower and upper $95 \%$ confidence limits for the $\mathrm{P}$ indices.

\section{Results}

\section{Soil P test results}

Across all experimental sites, P-CAL varies between 9.0-351 mg $\mathrm{P} \mathrm{kg}^{-1}$ (Table 2). According to the Austrian fertilization guidelines (Bundesministerium für Land- und Forstwirtschaft, Umwelt- und
Wasserwirtschaft, 2017) this covers the full range of $\mathrm{P}$ availability classes from very low $\left(<26 \mathrm{mg} \mathrm{P} \mathrm{kg}^{-1}\right)$ to very high $\left(>174 \mathrm{mg} \mathrm{P} \mathrm{kg}^{-1}\right.$ ). The coefficient of variation of P-CAL across all sites is $77 \%$. Across all sites, P-DGT varies between 10.7-788 $\mathrm{g} \mathrm{L}^{-1}$, with a mean of $206 \mu \mathrm{g} \mathrm{L}^{-1}$, and a coefficient of variation of $97 \%$, covering potentially P-deficient (Mason et al. 2010a, b; Nawara et al. 2017; Speirs et al. 2013) up to luxury $\mathrm{P}$ availability levels (Fig. 1).

Whereas the linear correlation between P-CAL and P-DGT is rather weak $\left(\mathrm{R}^{2}=0.52\right)$ if all data are included, we observe strong linear relations (Fig. 2) at each individual experimental site, with $\mathrm{R}^{2}>0.83$. As indicated by the slopes of the relations, there is a clear difference between the soils from the eastern ( $\mathrm{P}$ $\left.\mathrm{DGT}=1.73 \mathrm{P}-\mathrm{CAL}-65.3 ; \mathrm{R}^{2}=0.77\right)$ and western sites $\left(\mathrm{P}-\mathrm{DGT}=3.80 \mathrm{P}-\mathrm{CAL}-50.4 ; \mathrm{R}^{2}=0.86\right)$. Note that P-CAL in the non-calcareous, fine-textured soils of the western sites does not exceed $\sim 170 \mathrm{mg} \mathrm{P}$ $\mathrm{kg}^{-1}$ whereas approaches $\sim 350 \mathrm{mg} \mathrm{P} \mathrm{kg}^{-1}$ in the calcareous sandy soils of the eastern locations (Fig. 2). Conversely, the range of measured P-DGT is not related to the carbonate and sand content of the soils (Fig. 2). The average ratio between P-CAL and P-DGT is more than two times larger at the eastern (Fuchsenbigl and Rutzendorf) compared to the western sites (Rottenhaus and Grabenegg) (Table 2). Even though the P-CAL:P-DGT ratio should not be interpreted as $\mathrm{Kd}$, it is indicative of a lower P intensity and resupply in the sandy, calcareous soils of the eastern sites.

Grain yields in relation to site and soil properties

Means and standard deviations of grain yields of wheat and barley are displayed in Table 1 . Wheat was

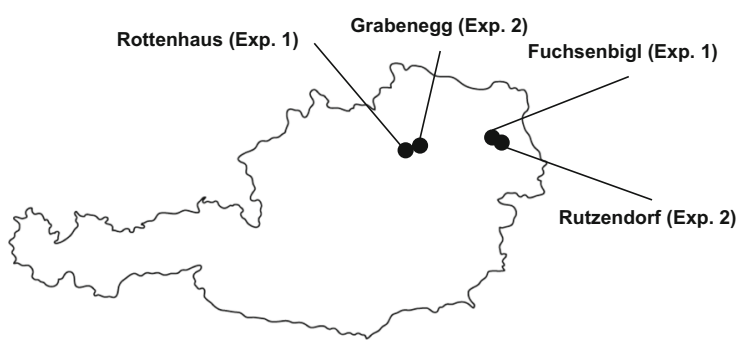

Fig. 1 Map of Austria depicting the geographic locations of the experimental sites of this study. Experiment 1 is established at Rottenhaus (western site) and Fuchsenbigl (eastern site), Experiment 2 at Grabenegg (western) and Rutzendorf (eastern) 


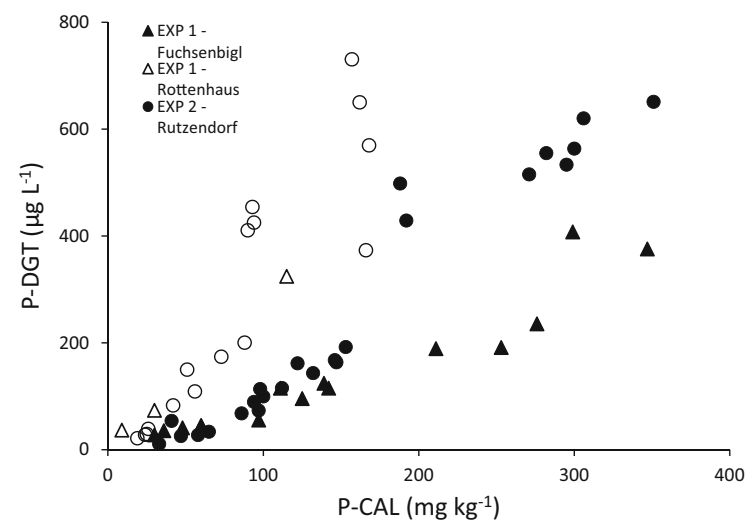

Fig. 2 Scatterplots of P-CAL versus P-DGT for the responsive plots $(\mathrm{N}=58)$. Data of the two experiments are presented separately for the individual sites Fuchsenbigl, Rottenhaus, Rutzendorf and Grabenegg. Soils from the eastern sites are shown as filled, those from the western sites with open symbols

grown in Experiment 1, with on average 16\% higher yields at site Rottenhaus compared to Fuchsenbigl. Barley grain yields obtained in Experiment 2 varied more pronouncedly among the sites, with $40 \%$ higher yields at Grabenegg compared to Rutzendorf. This yield pattern across sites is consistent with related differences in soil and site conditions (Table 1). The lower yields of both crops at the sites Fuchsenbigl and Rutzendorf are associated with lower water availability as indicated by lower precipitation and higher temperatures (Table 1). As estimated from published climate data (Harlfinger and Knees 1999) for the nearby stations Petzenkirchen (western sites) and Fuchsenbigl (eastern sites), the difference of the climatic water balance amounts to $\sim 200 \mathrm{~L} \mathrm{~m}^{-2}$ $\mathrm{a}^{-1}$, with a slightly negative balance at the eastern sites $(\sim-50 \mathrm{~mm})$. Moreover, these sites are also less favorable in terms of water holding capacity as indicated by the larger sand contents (Table 1).

\section{Correlation of relative grain yield to soil $\mathrm{P}$ tests}

Figure 3 shows the correlation of relative grain yield to P-CAL and P-DGT, respectively. Data are presented for crops separately (wheat, barley) and all crops together. In all cases, the Mitcherlich-type fits of grain yield are superior for P-DGT compared to P-CAL. As indicated by $\mathrm{R}^{2}$, additional $16-19 \%$ of the variation in the correlation of soil-test $P$ vs. grain yield can be explained by DGT as compared to P-CAL. The correlation between grain yield and $\mathrm{P}$ tests is generally stronger for barley as compared to wheat, with P-DGT explaining $42 \%$ of the variation of relative yield for the latter. When data for both crops are pooled, P-DGT explains $34 \%$ of the relative yield variation while only $18 \%$ are explained by P-CAL (Fig. 3).

Similarly, Fig. 4 displays the correlation of relative wheat grain yield to P-CAL and P-DGT including the data of both crops, but presented separately for the sandy, calcareous eastern, and finely-textured, noncalcareous western sites. The goodness of fits is generally weaker at the western sites, with both soil tests explaining $27-28 \%$ of the yield variation. At the western sites, P-DGT $\left(\mathrm{R}^{2}=0.50\right)$ performs clearly better than P-CAL $\left(\mathrm{R}^{2}=0.33\right)$, explaining additional $17 \%$ of the variation.

\section{Response of plant $\mathrm{P}$ uptake to soil $\mathrm{P}$ tests}

Figure 5 shows the relation between $P$ test results and $\mathrm{P}$ concentrations in wheat grains (Panels $\mathrm{A}$ and $\mathrm{B}$ ), Panels $\mathrm{C}$ and $\mathrm{D}$ the corresponding $\mathrm{P}$ uptake. Compared to P-CAL, P-DGT performs clearly superior in explaining additional $18 \%$ of the variation in $\mathrm{P}$ concentration, and additional $27 \%$ of $\mathrm{P}$ uptake in wheat grain.

\section{Critical values below which P deficiency occurs}

Critical values of $\mathrm{P}$ deficiency are compiled in Table 2 for both soil tests along with the related ranges of extracted soil P. The confidence intervals (95\%) are presented in parentheses. The critical values are presented only for a RY of $80 \%$, because of the large variation at higher RY levels. The critical values for P-DGT are clearly larger for barley as compared to wheat (Table 2). As indicated by the substantial overlap of the confidence intervals, there is no significant difference between the critical values for P-DGT between the western and eastern sites. On the contrary, the sites are clearly different in terms of the critical values for P-CAL (Table 2). 

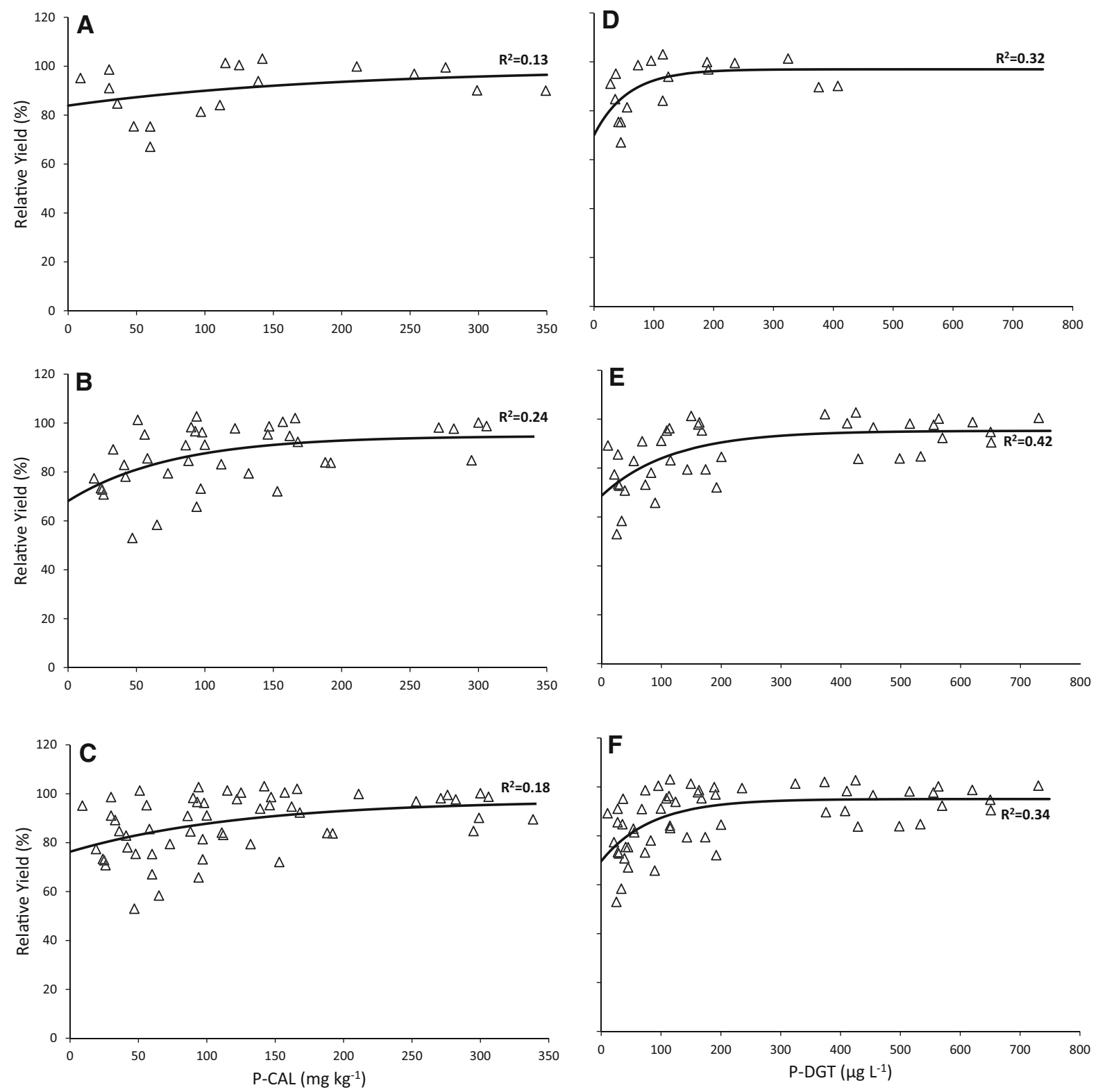

Fig. 3 Relation between relative grain yield of wheat (Panels A, $\mathrm{D} ; \mathrm{n}=18$ ), barley (Panels B, E; $\mathrm{n}=40$ ) and all crops (Panels C, $\mathrm{F} ; \mathrm{n}=58$ ), respectively, and the soil tests P-CAL (Panels A-C) and P-DGT (Panels D-F). Only data from responsive plots are

\section{Discussion}

P-DGT is less affected by soil chemistry than equilibrium-type CAL extraction

DGT has gained recognition as an accurate method to measure labile species in aquatic ecosystems, and has

included. Symbols (triangles) show measured data, solid lines Mitscherlich-type fits to the data. The goodness of fit is given as coefficient of determination $\left(\mathrm{R}^{2}\right)$

been applied to soils and sediments to measure the bioavailability of nutrients and toxicants. More recently, the technique has been utilized by researchers to predict plant response to $\mathrm{P}$, among other elements, and as a tool to assess fertilization requirements in $\mathrm{P}$ deficient soils. Our study sought to determine whether DGT has the potential to accurately 

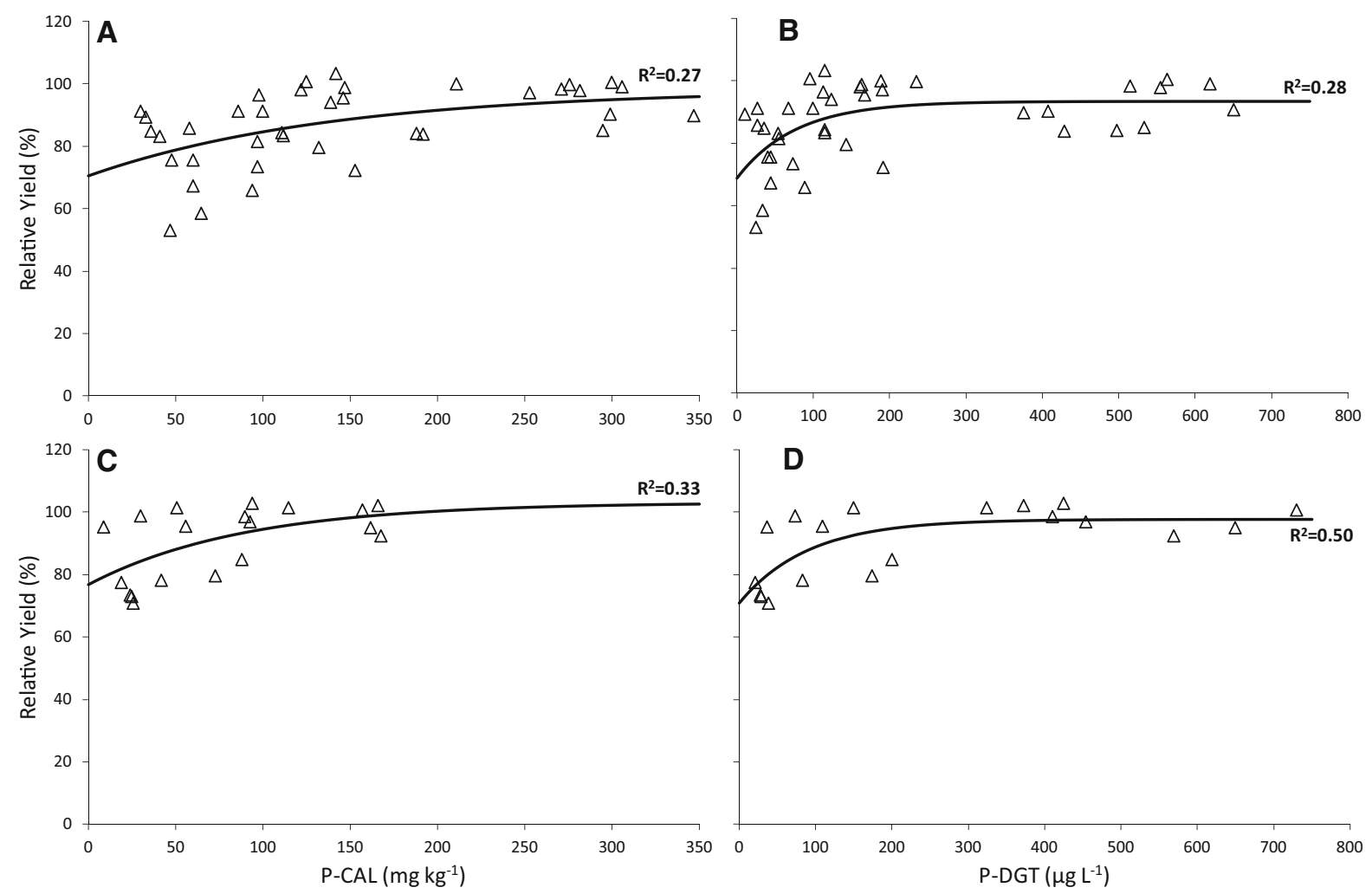

Fig. 4 Relation between relative grain yield (wheat and barley, pooled) grown at the eastern (Panels $\mathrm{A}, \mathrm{B} ; \mathrm{n}=38$ ) and western sites (Panels $C, D ; n=19$ ), respectively, and the soil tests P-CAL (Panels A, C) and P-DGT (Panels B, D). Only data from

predict plant-available $\mathrm{P}$ across several sites in eastern Austria, and whether it provides any advantages over the standard P extraction protocol used in Austria and Germany (P-CAL).

Consistent with the clear difference between the sandy, calcareous soils of the eastern, and the finelytextured non-calcareous soils of the western sites (Table 1), the linear relation between P-DGT and P-CAL was only moderate $\left(\mathrm{R}^{2}=0.52\right)$ across all sites and experiments. When the data were divided into soils from eastern (Rutzendorf, Fuchsenbigl) and western sites (Rottenhaus, Grabenegg), the goodness of fits for the linear relations improved to $R^{2}=0.77$ and $\mathrm{R}^{2}=0.86$, respectively. We obtained further improvements when each experiment was treated separately, with $\mathrm{R}^{2}$ of the linear relations ranging between 0.83 and 0.99 , and regression slopes depending on the experimental site. These results indicate that the methods are correlated if there is little variation in soil properties, but results diverge if soil responsive plots are included. Symbols (triangles) show measured data, solid lines Mitscherlich-type fits to the data. The goodness of fit is given as coefficient of determination $\left(\mathrm{R}^{2}\right)$

characteristics are more variable. As shown in Table 1, the sites differ largely in soil texture and carbonate equivalent, with low sand and relatively high clay and silt contents, associated with smaller P-CAL concentrations in the non-calcareous soils of the eastern sites. Site Grabenegg differs from the other locations also in terms of distinctively lower SOC content (Table 1).

We observed a striking difference between the soils from the western and eastern sites regarding the range of $\mathrm{P}$ extracted by P-DGT and P-CAL. While P-CAL in the soils at the eastern sites increases over the full range of measured P-DGT concentrations, it does not exceed $\sim 170 \mathrm{mg} \mathrm{P} \mathrm{kg}^{-1}$ at the western sites, while P-DGT continues to increase (Fig. 2). As shown by Schüller (1969), the initial $\mathrm{pH}$ of the CAL extraction solution of 4.1 increases during extraction up to $\sim 4.8$ in the presence of carbonates, but remains near the initial $\mathrm{pH}$ in non-calcareous soils. Lower extraction yields in the non-calcareous soils of the eastern sites could therefore be related to the protonation of surface 

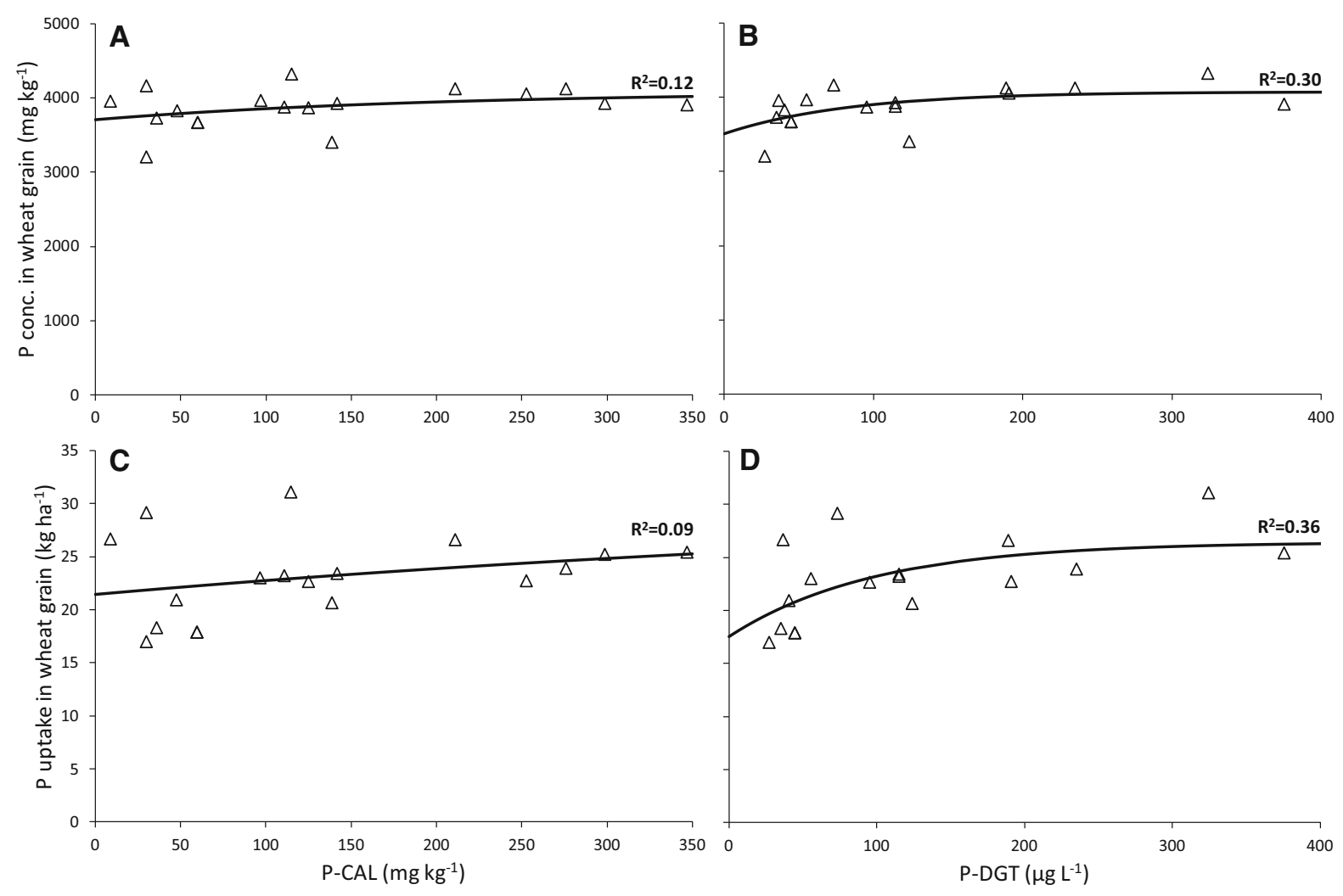

Fig. 5 Relations between soil tests, and phosphorus concentrations (Panel A: P-CAL; Panel B: P-DGT) and uptake (Panel C: P-CAL; Panel D: P-DGT) in wheat grain, respectively. Only data $(n=18)$ from responsive plots are included. Symbols

sites due to the lower extraction $\mathrm{pH}$, and subsequent decrease of $\mathrm{P}$ desorption from hydrous oxides of $\mathrm{Al}$ and $\mathrm{Fe}$ (Barrow, 2017). Moreover, in the presence of $\mathrm{Ca}$ phosphates, the large $\mathrm{Ca}$ concentration in the extraction solution is likely to decrease their solubility (Schüller 1969). In contrast, DGT is operating as a zero sink without considerable modification of soil $\mathrm{pH}$ or ion concentration, allowing for $\mathrm{P}$ desorption that is much less affected by soil chemistry.

DGT outperforms P-CAL in predicting grain yield and $\mathrm{P}$ uptake

Previous work has shown that DGT generally outperforms conventional, equilibrium-type batch extractions in predicting crop yields and $\mathrm{P}$ uptake in highly weathered soils (Menzies et al. 2005; McBeath et al. 2007; Mason et al. 2010a, b; Six et al. 2013) while this could not be confirmed for less developed European soils (Nawara et al. 2017). Nawara et al. (2017) (triangles) show measured data, solid lines Mitscherlich-type fits to the data. The goodness of fit is given as coefficient of determination $\left(\mathrm{R}^{2}\right)$

suggested that due to strong $\mathrm{P}$ fixation in highly weathered (sesquioxide-rich) soils, $\mathrm{P}$ availability to crops is mainly controlled by intensity and diffusion, which is better mimicked by DGT. Phosphorus availability in less developed soils with low fixation potential, however, appears to be controlled by quantity, explaining why conventional $\mathrm{P}$ tests targeting larger P pools perform equally well or better than intensity tests such as DGT in European soils (Nawara et al. 2017).

Our data obtained from long-term experiments in eastern Austria show consistently stronger predictive power of DGT for crop yield and P uptake compared to the quantity-type CAL extraction, explaining additional 16 to $19 \%$ of the overall variation of the barley and wheat grain yield responses (Fig. 3), 18\% of the $\mathrm{P}$ concentration, and $27 \%$ of the $\mathrm{P}$ uptake in wheat grains (Fig. 5). While both soil test perform only moderately on the sandy calcareous soils of the western sites, DGT clearly outperforms P-CAL at the eastern sites, 
explaining $50 \%$, i.e., $17 \%$ more than P-CAL of the crop yield variation (Fig. 4). This finding could be related to the limitation of P-CAL in desorbing plantavailable $\mathrm{P}$ at the lower extraction $\mathrm{pH}$ obtained in the non-calcareous soils, which is indicated by the narrow range of P-CAL (Fig. 2). In turn, this suggests that the zero sink that is induced by DGT without modification of the soil $\mathrm{pH}$ allows for desorption of a $\mathrm{P}$ pool that can be accessed by plants roots. It has been shown that $\mathrm{P}$ desorption rates assessed by DGT are less affected by soil $\mathrm{pH}$ and texture (Menezes-Blackburn et al. 2016), and that predictions of yield responses by DGT are less influenced by $\mathrm{P}$ buffer power than those by soil pore water and P quantity tests (Degryse et al. 2009).

Note that the experimental sites included in the study of Nawara et al. (2017) are from U.K., western France, Belgium, northern Germany, and Sweden, generally representing areas of considerably higher water availability compared to our sites in Eastern Austria (Dezsi et al. 2018). The water availability is defined as the difference between annual precipitation and potential evapotranspiration (Dezsi et al. 2018). The lower water availability during the growing season at our study sites implies that $\mathrm{P}$ re-supply to plants from the solid phase was more constrained, rendering intensity and diffusion control more important than at the study sites of Nawara et al. (2017).

We suggest that the superior performance of DGT in the temperate soils of our study can be explained by the mechanistic similarity between DGT and P uptake in plants (Degryse et al. 2009). While Nawara et al. (2017) view P-DGT merely as intensity factor of P availability because of the rather short deployment time of $24 \mathrm{~h}$, we refer to the more common interpretation as zero sink mimicking diffusion-limited $\mathrm{P}$ uptake (Degryse et al. 2009; Menezes-Blackburn et al. 2016). While $P$ availability in temperate regions may indeed be controlled to a larger extent by $\mathrm{P}$ quantity in bulk soil material, this does not apply to rhizosphere soil, especially if available water is limited (Gahoonia et al. 1994). The literature provides overwhelming evidence for diffusion-limited $\mathrm{P}$ uptake based on rhizosphere modelling and experimental work (Barber 1995; Dunham and Nye 1976; Hinsinger et al. 2011). For fast-growing crops, $\mathrm{P}$ diffusion may be also limited by low rates of $\mathrm{P}$ desorption from the solid phase (Smolders et al. 2021). Diffusion and/or desorption-limited $\mathrm{P}$ uptake is further supported by direct observations using chemical imaging consistently showing depletion of total and available $\mathrm{P}$ in the rhizosphere of wheat and numerous other crops even in weakly to moderately weathered soils (Hoefer et al. 2015; Hummel et al. 2021; Santner et al. 2012; Kreuzeder et al. 2018; Wagner et al. 2020). Together, this provides strong evidence that $\mathrm{P}$ availability is generally limited by diffusion and re-supply from the solid phase.

While the standard deployment time of $24 \mathrm{~h}$ is too short to fully account for the resupply potential of many soils (Nawara et al. 2017; Santner et al. 2015), P-DGT was shown to be correlated with the desorption rate constant of the quickly desorbing $\mathrm{P}$ fraction (Santner et al. 2015). Moreover, even in soils with a slow-desorbing P pool, the quickly-desorbing $\mathrm{P}$ pool assessed by DGT can represent a relevant fraction of the total available pool (Santner et al. 2015; Smolders et al. 2021), and has been shown to be related to the $P$ status of soils (Menezes-Blackburn et al. 2016). The generally weaker performance of the CAL extraction, especially if applied to soils with variable properties probably also reflects the methodological constraints of equilibrium-type extraction procedures as discussed above.

Critical values of $\mathrm{P}$ deficiency for P-DGT are sensible to crop $\mathrm{P}$ demands but not affected by soil properties

The critical values for P-DGT derived from the Mitscherlich-type fits for barley and wheat grain yield differ considerably from each other (Table 2), reflecting the different uptake behavior and $\mathrm{P}$ requirements of these crops (Spiegel et al. 2001). For wheat, the critical value of $\mathrm{P}$ deficiency determined by DGT at $80 \% \mathrm{RY}$ is $26.2 \mu \mathrm{g} \mathrm{L}^{-1}$ which compares to $59 \mu \mathrm{g} \mathrm{L}^{-1}$ reported by McBeath et al. (2007) based on Australian field experiments.

The critical values of deficiency based on P-CAL are considerably larger at the eastern sites (Fuchsenbigl, Rutzendorf) compared to the western locations (Rottenhaus, Grabenegg) (Table 2). This is consistent with the distinct differences of P extractability by CAL (Fig. 2), indicating a strong influence of soil chemistry, in particular carbonate content. Such a difference is not observed for the critical values of P-DGT which indicates - consistent with theory - that this soil test is less influenced by soil properties. The critical values of $\mathrm{P}$ deficiency derived in our study for P-CAL 
(44.9 $\mathrm{mg} \mathrm{kg}^{-1}$ for barley, $24.6 \mathrm{mg} \mathrm{kg}^{-1}$ for all crops, Table 2) compare well with the boundary between the classes "low" and "adequate" (46 mg kg-1) of the Austrian guidelines for fertilization (Bundesministerium für Land- und Forstwirtschaft, Umwelt und Wasserwirtschaft 2017; Jordan-Meille et al. 2012).

Both crops produced clearly larger absolute yields at the western sites (Table 1). This is related to the dryer and warmer climate at the eastern sites (Table 1), and subsequent lower water availability and reduced diffusional $\mathrm{P}$ fluxes and uptake rates. While DGT fluxes were measured at $80 \%$ water holding capacity, rates of $\mathrm{P}$ diffusion are expected to decrease with soil moisture (Olesen et al. 2001), resulting in lower $P$ and other nutrients supply at a given value of P-DGT. Similarly, water availability could be an important factor contributing to the variation of critical values of P deficiency reported by Nawara et al. (2017) for European sites, and, in addition to differential $\mathrm{P}$ fixation properties, differences between European (Nawara et al. 2017) and highly weathered soils of Australia and other regions (Mason et al. 2010a, b; Speirs et al. 2013). It follows that $P$ indices could be improved and become more generally applicable if water availability would be considered.

\section{Conclusions}

This study contributes to a body of work that evaluates novel methods to assess plant available $\mathrm{P}$ in soils under field conditions. Specifically, we evaluated the suitability of DGT as a field test to predict plant available $\mathrm{P}$ and consequently make fertilizer recommendations to growers. P-DGT is less influenced by soil properties when compared to the Austrian and German standard $\mathrm{P}$ test (P-CAL) and provides a more accurate prediction of crop yield and $\mathrm{P}$ uptake. We argue that our findings are consistent with $\mathrm{P}$ availability limited by diffusion and re-supply in the weakly to moderately weathered but water-limited soils of our study. We also suggest that standard deployment of DGT for $24 \mathrm{~h}$ should be considered not only as intensity method but may properly reflect a relevant part of the plantavailable $\mathrm{P}$ pool also in soils of temperate regions.

Across different sites, the predictive power of P-DGT might be limited by differential water availability as $\mathrm{P}$ diffusion is directly affected by soil moisture. A way forward to account for this could make use of pedotransfer functions such as the one of Oleson et al. (2001) to tabulate impedance factors for different moisture contents based on simple soil textural information. This information could be combined with estimates of the climatic water balance, e.g., aridity indices to obtain correction factors for the effect of water availability on the critical P test values.

Acknowledgements We wish to acknowledge the support of Veronika Slavik, Christoph Höfer, and Paul Schabl during the laboratory work and funds received from the Austrian Research Promotion Agency (FFG) through the Research Studio Austria FERTI-MINE [Project number: 844744].

Authors' contributions WWW (Study design, supervision, data analysis, interpretation and writing). BH (Experimental work including soil analysis, contributions to data analysis and writing). HS (Maintaining long-term field experiments, providing soil and plant data and records of the field experiment). JS (Contributions to study design, supervision and interpretation). MP (Contributions to study design, supervision of laboratory work, interpretation).

Funding Open access funding provided by University of Natural Resources and Life Sciences Vienna (BOKU). Funds were received from the Austrian Research Promotion Agency (FFG) through the Research Studio Austria FERTI-MINE [Project number: 844744].

Availability of data and material Upon request from the corresponding author.

Code availability Not applicable.

\section{Declarations}

Conflict of interest The authors declared that they have no conflict of interest.

Ethical approval Not applicable.

Consent to participate Not applicable.

Consent for publication Not applicable.

Open Access This article is licensed under a Creative Commons Attribution 4.0 International License, which permits use, sharing, adaptation, distribution and reproduction in any medium or format, as long as you give appropriate credit to the original author(s) and the source, provide a link to the Creative Commons licence, and indicate if changes were made. The images or other third party material in this article are included in the article's Creative Commons licence, unless indicated otherwise in a credit line to the material. If material is not included in the article's Creative Commons licence and your intended use is not permitted by statutory regulation or exceeds the permitted use, you will need to obtain permission directly 
from the copyright holder. To view a copy of this licence, visit http://creativecommons.org/licenses/by/4.0/.

\section{References}

Barber SA (1995) Soil nutrient bioavailability: a mechanistic approach, 2nd edn. John Wiley, New York

Barrow NJ (2017) The effects of $\mathrm{pH}$ on phosphate uptake from the soil. Plant Soil 410:401-410

Bundesministerium für Land- und Forstwirtschaft, Umwelt und Wasserwirtschaft (2017) Richtlinie für die sachgerechte Düngung im Ackerbau und Grünland. Anleitung zur Interpretation von Bodenuntersuchungsergebnissen in der Landwirtschaft, $7^{\text {th }}$ Edition, $115 \mathrm{p}$

Burkitt LL, Mason SD, Dougherty WJ (2016) The ability of the DGT soil phosphorus test to predict pasture response in Australian pasture soils-a preliminary assessment. Soil Use Manag 32:27-35

Cole CV, Olsen SR (1959) Phosphorus availability in calcareous soils. II effects of exchangeable phosphorus and soil texture on phosphorus availability. Soil Sci Soc Am Proc 23:119-121

De Jager PC, Claassens AS (2005) Long-term phosphate desorption kinetics of an acid sandy clay soil from Mpumalanga, South Africa. Commun Soil Sci Plant Anal 36:309-319

Degryse F, Smolders E, Zhang H, Davison W (2009) Predicting availability of mineral elements to plants with the DGT technique: a review of experimental data and interpretation by modelling. Environ Chem 6:198-218

Dezsi S, Mîndrescu M, Petrea D, Rai PK, Hamann A, Nistor M (2018) High-resolution projections of evapotranspiration and water availability for Europe under climate change. Int J Climatol 38:3832-3841

Dunham RJ, Nye PH (1976) The influence of water content on the uptake of ions by roots. III. Phosphate, potassium, calcium and magnesium uptake and concentration gradients in soil. J Appl Ecol 13:967-984

FAO (2006) Guidelines for soils description, 4th edn. Food and Agriculture Organization of the United Nations, Rome

Fox RL (1981) External phosphorus requirements of crops. Chemistry in the soil environment. ASA-SSSA, Madison, pp 224-239

Gahoonia TS, Raza S, Nielsen NE (1994) Phosphorus depletion in the rhizosphere as influenced by soil moisture. Plant Soil 159:213-218

Harlfinger O, Knees G (1999) Climate handbook for the Austrian soil taxation (in German). Mitteilungen Der Österreichischen Bodenkundlichen Gesellschaft 58:1-196

Hinsinger P, Brauman A, Devau N, Gérard F, Jourdan C, Laclau J-P, Le Cadre E, Jaillard B, Plassard C (2011) Acquisition of phosphorus and other poorly mobile nutrients by roots. Where do plant nutrition models fail? Plant Soil 348:29-61

Höfer C, Santner J, Puschenreiter M, Wenzel WW (2015) Localized metal solubilisation in the rhizosphere of Salix smithiana upon sulfur application. Environ Sci Technol 49:4522-4529. es505758j(seniorauthor)
Holford JCR, Mattingly GEG (1976) Phosphate adsorption and availability of phosphate. Plant Soil 44:377-389

Hummel C, Boitt G, Santner J, Lehto NJ, Condron L, Wenzel WW (2021) Co-occurring increased phosphatase activity and labile $\mathrm{P}$ depletion in the rhizosphere of Lupinus angustifolius assessed with a novel, combined 2D-imaging approach. Soil Biol Biogeochem 153:107963

IUSS Working Group WRB (2014) World Reference Base for Soil Resources 2014. International soil classification system for naming soils and creating legends for soil maps. World Soil Resources Reports No. 106. FAO, Rome

Jordan-Meille L, RubÆk GH, Ehlert PAI, Genot V, Hofman G, Goulding K, Recknagel J, Provolo G, Barraclough P (2012) An overview of fertilizer-P recommendations in Europe: soil testing, calibration and fertilizer recommendations. Soil Use Manag 28:419-435

Koster M, Reijnders L, van Oost NR, Peijnenburg WGJM (2005) Comparison of the method of diffusive gels in thin films with conventional extraction techniques for evaluating zing accumulation in plants and isopods. Environ Pollut 133:103

Kreuzeder A, Santner J, Scharsching V, Oburger E, Höfer C, Hann S, Wenzel WW (2018) In situ observation of localized, sub-mm scale changes of phosphorus biogeochemistry in the rhizosphere. Plant Soil 424:573-589

Lookman R, Freese D, Merckx R, Vlassak K, Van Riemsdijk WH (1995) Long-term kinetics of phosphate release from soil. Environ Sci Technol 29:1569-1575

Maguire RO, Sims JT, Foy RH (2001) Long-term kinetics for phosphorus sorption-desorption by high phosphorus soils from Ireland and the Delmarva Peninsula, USA. Soil Sci 166:557-565

Mason S, McNeill A, Mclaughlin MJ, Zhang H (2010a) Prediction of wheat response to an application of phosphorus under field conditions using diffusive gradients in thinfilms (DGT) and extraction methods. Plant Soil 337:243-258

Mason S, McNeill A, McLaughlin MJ (2010b) Prediction of wheat response to an application of phosphorus under field conditions using diffusive gradients in thin-films (DGT) and extraction methods. Plant Soil 337:243-258

McBeath TM, McLaughlin MJ, Armstrong RD, Bell M, Bolland MDA, Conyers MK, Holloway RE, Mason SD (2007) Predicting the response of wheat (Triticum aestivum L.) to liquid and granular phosphorus fertilisers in Austrialian soils. Aust J Soil Res 45:448-458

Menezes-Blackburn D, Zhang H, Stutter M, Giles CD, Darch T, George TS, Shand C, Lumsdon D, Blackwell M, Wearing C, Cooper P, Wendler R, Brown L, Haygarth PM (2016) A holistic approach to understanding the desorption of phosphorus in soils. Environ Sci Technol 50:3371-3381

Menzies NW, Kusumo B, Moody PW (2005) Assessment of P availability in heavily fertilized soils using the diffusive gradient in thin films (DGT) technique. Plant Soil 269:1-9

Mundus S, Carstensen A, Husted S (2017) Predicting phosphorus availability to spring barley (Hordeum vulgare) in agricultural soils of Scandinavia. Field Crop Res 212:1-10

Murphy J, Riley J (1962) A modified single solution method for the determination of phosphate in natural waters. Anal Chimica Acta 27:31-36 
Nawara S, Van Dael T, Merckx R, Amery F, Elsen A, Odeurs W, Vandendriessche H, McGrath S, Roisin C, Jouany C, Pellerin S, Denoroy P, Eichler-Löbermann B, Börjesson G, Goos P, Akkermans W, Smolders E (2017) A comparison of soil tests for available phosphorus in long-term field experiments in Europe. Eur J Soil Sci 68:873-885

Neyroud JA, Lischer P (2003) Do different methods used to estimate soil phosphorus availability across Europe give similar results? J Plant Nutr Soil Sci 166:422-431

Nolan AL, Zhang H, McLaughlin MJ (2005) Prediction of zinc, cadmium, lead and copper 49 bioavailability to wheat in contaminated soils using chemical speciation, diffusive gradients in thin films, extraction, and isotope dilution techniques. J Environ Qual 34:496

Olesen T, Moldrup P, Yamaguchi T, Rolston DE (2001) Constant slope impedance factor model for predicting the solute diffusion coefficient in unsaturated soil. Soil Sci 166:89-96

ÖNORM EN 15933 (2012) Schlamm, behandelter Bioabfall und Boden - Bestimmung des pH-Werts

ÖNORM L 1080 (1999) Chemische Bodenuntersuchungen Bestimmung von Stickstoff nach Kjeldahl

ÖNORM L 1084 (2006) Chemische Bodenuntersuchungen Bestimmung von Carbonat

ÖNORM L 1087 (2006) Chemische Bodenuntersuchungen Bestimmung von "pflanzenverfügbarem" Phosphor und Kalium nach der Calcium-Acetat-Lactat (CAL)-Methode

ÖNORM L 1061-2 (2019) Physikalische Bodenuntersuchungen - Bestimmung der Korngrößenverteilung des Mineralbodens in land- und forstwirtschaftlich genutzten Böden Teil 2: Feinboden

Peaslee DE, Phillips RE (1981) Phosphorus dissolution-desorption in relation to bioavailability and environmental pollution. Chemistry in the soil environment. ASA-SSSA, Madison, pp 241-259

Santner J, Prohaska T, Luo J, Zhang H (2010) Ferrihydrite containing gel for chemical imaging of labile phosphate species in sediments and soils using diffusive gradients in thin films. Anal Chem 82:7668-7674

Santner J, Zhang H, Leitner D, Schnepf A, Prohaska T, Puschenreiter M, Wenzel WW (2012) High-resolution chemical imaging of labile phosphorus in the rhizosphere of Brassica napus L. cultivars. Environ Exp Bot 77:219-226

Santner J, Mannel M, Burrell LD, Höfer C, Kreuzeder A, Wenzel WW (2015) Phosphorus uptake by Zea mays L. is quantitatively predicted by infinite sink extraction of soil P. Plant Soil 386:371-383

Schüller H (1969) The CAL-method, a new method to determine the available phosphate in Soils [in German]. Zeitschrift Für Pflanzenernährung Und Bodenkunde 123:49-63

Six L, Smolders E, Merckx R (2013) The performance of DGT versus conventional soil phosphorus tests in tropical soils - maize and rice responses to $\mathrm{P}$ application. Plant Soil 366:49-66

Smolders E, Nawara S, De Cooman E, Merckx R, Martens S, Elsen A, Odeurs W, Vandendriessche H, Santner J, Amery
F (2021) The phosphate desorption rate in soil limits phosphorus bioavailability to crops. Eur J Soil Sci 72:221-233

Song J, Zhao FJ, Luo YM, McGrath SP, Zhang H (2004) Copper uptake by Elsholtzia splendens and Silene vulgarisand assessment of copper phytoavailability in contaminated soils. Environ Pollut 128:307-315

Speirs SD, Scott BJ, Moody PW, Mason SD (2013) Soil phosphorus tests II: a comparison of soil test-crop response relationships for different soil tests and wheat. Crop Pasture Sci 64:469-479

Spiegel H, Lindenthal T, Mazorek M, Ploner A, Freyer B, Köchl A (2001) Ergebnisse von drei 40-jährigen P-Dauerversuchen in Österreich. 1. Mitteilung: Auswirkungen ausgewählter P-Düngerformen und -mengen auf den Ertrag und die PCAL/DL-Gehalte im Boden. Die Bodenkultur 52:1-17

Spiegel H, Sandén T, Dersch G, Baumgarten A, Gründling R, Franko U (2018) Soil organic matter and nutrient dynamics following different management of crop residues at two sites in Austria. In: Zornoza MAMR (ed) Soil management and climate change. Academic Press, London, pp 253-365

Taddesse AM, Claassens AS, de Jager PC (2008) Long-term phosphorus desorption using dialysis membrane tubes filled with iron hydroxide and its effect on phosphorus pools. J Plant Nutr 31:1507-1522

Tandy S, Mundus S, Yngvesson J, de Bang TC, Lombi E, Schjoerring JK, Husted S (2011) The use of DGT for prediction of plant available copper, zinc and phosphorus in agricultural soils. Plant Soil 346:167-180

Wagner S, Höfer C, Puschenreiter M, Wenzel WW, Oburger E, Hann S, Robinson B, Kretzschmar R, Santner J (2020) Arsenic redox transformations and cycling in the rhizosphere of Pteris vittata and Pteris quadriaurita. Environ Exp Botany 177:104122

Zhang H, Davison W (1995) Performance characteristics of diffusion gradients in thin-films for the in-situ measurement of trace-metals in aqueous solution. Anal Chem 67:3391-3400

Zhang H, Davison W, Gadi R, Kobayashi T (1998) In situ measurement of dissolved phosphorus in natural waters using DGT. Anal Chim Acta 370:29-38

Zhang H, Zhao FJ, Sun B, Davison W, McGrath SP (2001) A new method to measure effective soil solution concentration predicts copper availability to plants. Environ Sci Technol 35:2602-2607

Zhang H, Lombi E, Smolders E, McGrath S (2004) Kinetics of $\mathrm{Zn}$ releases in soils and prediction of $\mathrm{Zn}$ concentration in plants using diffusive gradients in thin films. Environ Sci Technol 38:3608-3613

Publisher's Note Springer Nature remains neutral with regard to jurisdictional claims in published maps and institutional affiliations. 